Kilkoda, A.K. • T. Nurmala $\cdot$ D. Widayat

\title{
Pengaruh keberadaan gulma (Ageratum conyzoides dan Boreria alata) terhadap pertumbuhan dan hasil tiga ukuran varietas kedelai (Glycine max L. Merr) pada percobaan pot bertingkat
}

\author{
Effect of the existence of weeds (Ageratum conyzoides and Boreria alata) \\ against on the growth and yield soybean (Glycine max L. Merr) \\ variety of three sizes inlevel pot experiment
}

Diterima : 15 September 2015/Disetujui : 15 Oktober 2015 / Dipublikasikan : Oktober 2015

CDepartment of Crop Science, Padjadjaran University

\begin{abstract}
The experiment was conducted at Green House Faculty of Agriculture, University of Padjadjaran, Cikeruh Village, District Jatinangor, Sumedang regency, West Java. The purpose of this study was to examine the root exudates were found in weeds Ageratum conyzoides and Borreriaalata on the growth and yield of soybean. Experiments were carried out starting from the month of October 2014 to December 2014 using a factorial randomized complete block design. The first factor is the type of weed treatment consists of 3 levels, among others A.Conyzoides weeds, weeds B.alata and without weed (control). The second is the size of the seed treatment soybean varieties consisting of 3 levels. Total combined treatment is 9 combination treatment, with three replications, in order to obtain 27 treatment. The design of treatment is : Without Weeds + GepakKuning varieties (seeds of small size); Without Weeds + varieties Gema (seed medium size); Without Weeds + Grobogan varieties (large seed size); Weeds A. conyzoides + Gepak yellow (small size seeds); Weeds A. conyzoides + Gema (seed medium size); Weeds A. conyzoides + Grobogan (large seed size); Weeds B. alata + GepakKuning (small size seeds); Weeds B. alata + Gema (seed medium size); and Weeds B. alata + Grobogan (seed size). the results of experiment provide information that most of the parameters were observed in the components of growth shows the size of the treatment effect is tested seed
\end{abstract}

\footnotetext{
Dikomunikasikan oleh A. W. Irwan

Kilkoda, A.K. ${ }^{1}$ T. Nurmala ${ }^{2}$ D. D. Widayat ${ }^{2}$

1 Fakultas Pertanian Universitas Pattimura Ambon

2 Dept. Budadaya Pertanian Fakultas Pertanian Unpad

Korespondensi: boimkilkoda@gmail.com
}

varieties were not significantly different, except for the observation of the number of leaves at 8 WAP growth component, which has a variety Grobogan the number of leaves that more than two types of other varieties, as well as the interaction effect is only found in plant height parameter $8 \mathrm{WAP}$ observation.

Keywords : Weeds · Ageratum conyzoides . Borreria alata . Growth · Yield

Sari Percobaan dilaksanakan di rumah kaca Fakultas Pertanian Universitas Padjadjaran, Jatinangor, Kabupaten Sumedang, Jawa Barat. Tujuan dari penelitian ini adalah untuk menguji eksudat akar yang terdapat pada gulma Ageratum conyzoides dan Borreria alata terhadap pertumbuhan dan hasil tanaman kedelai. Percobaan dilakukan mulai dari bulan Oktober 2014 sampai dengan bulan Desember 2014 dengan menggunakan rancangan acak kelompok pola faktorial. Faktor perlakuan pertama adalah jenis gulma terdiri dari 3 taraf antara lain gulma $A$. Conyzoides, gulma $B$. alata dan tanpa gulma (kontrol). Perlakuan kedua adalah ukuran benih varietas kedelai yang terdiri dari 3 taraf. Total kombinasi perlakuan adalah 9 kombinasi perlakuan, dengan 3 kali ulangan, sehingga diperoleh 27 perlakuan. Rancangan perlakuan adalah Tanpa Gulma + varietas Gepak Kuning (benih ukuran kecil); Tanpa Gulma + varietas Gema (benih ukuran sedang); Tanpa Gulma + varietas Grobogan (benih ukuran besar); Gulma A. conyzoides + Gepak kuning (benih ukuran kecil); Gulma A. conyzoides + Gema (benih ukuran sedang); Gulma A. conyzoides + Grobogan (benih ukuran besar); Gulma B. alata + Gepak kuning (benih ukuran kecil); Gulma B. alata + Gema (benih ukuran sedang); Gulma B. alata + 
Grobogan (benih ukuran besar). Hasil penelitian ini memberikan informasi bahwa hampir sebagian besar parameter yang diamati pada komponen pertumbuhan memperlihatkan pengaruh perlakuan ukuran benih varietas yang dicobakan tidak berbeda nyata, kecuali pada pengamatan jumlah daun 8 mst komponen pertumbuhan, dimana varietas Grobogan mempunyai jumlah daun yang lebih banyak dibandingkan kedua jenis varietas lainnya, begitupun pada pengaruh interaksi hanya terdapat pada parameter tinggi tanaman pengamatan $8 \mathrm{mst}$.

Kata kunci : Gulma - Ageratum conyzoides . Borreria alata $\cdot$ Pertumbuhan $\cdot$ Hasil

\section{Pendahuluan}

Data statistik menunjukkan bahwa dalam kurun waktu lima belas tahun terakhir, rata-rata produktivitas kedelai nasional tidak mengalami perkembangan berarti dan stagnan di kisaran 1,1 1,3 ton/ha. Sementara itu, hasil penelitian menunjukkan bahwa melalui program PTT produksi kedelai di tingkat petani bisa mencapai 1,7 - 3,2 ton/ha. Beberapa varitas kedelai yang telah dilepas, produktivitasnya bisa mencapai lebih dari 3 ton/ha. Kesenjangan produktivitas yang cukup lebar ini merupakan indikasi penerapan teknologi budidaya kedelai oleh petani belum berada pada rel yang benar. Dengan demikian, produksi kedelai nasional sejak tahun 1992 terus merosot dan lebih banyak ditentukan oleh luas areal panen. Upaya meningkatkan produksi kedelai nasional dapat ditempuh dengan tiga pendekatan yaitu peningkatan produktivitas, peningkatan inten-sitas tanam dan perluasan areal tanam. Upaya peningkatan produktivitas dapat ditempuh melalui perbaikan varietas, perbaikan teknik budidaya dan menekan kehilangan hasil melalui perbaikan sistem panen dan pasca panen. Peningkatan intensitas tanam dengan menanam kedelai berturut-turut kurang baikkarena ada efek alelopati dari gulma terhadap tanaman kedelai. Gulma dapat merugikan karena menyebabkan penurunan kuantitas dan kualitas hasil panen. Penurunan kuantitas hasil panen yaitu pengurangan jumlah hasil yang dapat dipanen dan penurunan jumlah individu tanaman yang dipanen.

Ukuran benih kedelai yang berbeda (besar, sedang dan kecil) mengandung jumlah makanan cadangan berbeda, ukuran yang semakin besar akan mempengaruhi pertumbuhan kecambah kedelai. Jumlah benih yang diperlukan tergantung kepada ukuran benih, jarak tanam dan daya tumbuhnya. Untuk kedelai yang benihnya berukuran kecil dengan bobot 100 benih antara 7 $10 \mathrm{~g}$ diperlukan benih sekitar $35-40 \mathrm{~kg}$ per hektar. Untuk benih kedelai berukuran sedang dengan bobot 100 benih antara 11-15g diperlukan benih sekitar 40-45 kg per hektar, sedangkan untuk benih berukuran besar dengan bobot di atas $15 \mathrm{~g}$ diperlukan benih sekitar 45-50 $\mathrm{kg}$ per hektar (Roesmiyanto dkk, 1999). Bentuk dan besar biji bervariasi tergantung varietasnya.

Kehadiran gulma pada pertanaman akan menimbulkan kompetisi yang sangat serius dalam mendapatkan air, hara, cahaya matahari dan tempat tumbuh, dampaknya hasil tanaman tidak mampu menunjukkan potensi yang sebenarnya. Secara umum dapat dikatakan bahwa besarnya pengaruh kompetisi dengan gulma sangat ditentukan oleh lokasi atau kesuburan tanah, tanaman budidaya, jenis gulma, tingkat kelembaban tanah, tingkat pengelolaan lahan, pupuk, stadia tanaman, dan tingkat populasi gulmanya (Madkar dkk., 1986). Menurut Utomo dkk (1986), biaya tenaga kerja untuk penyiangan gulma bisa mencapai $65 \%$ dari total biaya produksi. Besarnya kerugian atau kehilangan hasil yang diakibatkan oleh gulma berbeda-beda untuk setiap jenis tanaman tergantung dari jenis tanaman, jenis gulma dan faktor-faktor pertumbuhan yang mempengaruhinya (Chozin, 2006). Menurut Smith (1985) dan Madkar dkk, (1986) dalam Susilo, (2004), kehilangan hasil akibat gulma pada tanaman budidaya ditentukan oleh efisiensi kompetisi antara tanaman dan gulma, jenis gulma, tingkat kesuburan tanah, varietas, alelopati, pengelolaan air, jarak tanam, kepadatan gulma dan cara tanam.

Banyak spesies gulma menimbulkan kerugian dalam budidaya tanaman yang berakibat pada berkurangnya jumlah dan kualitas hasil panen. Rice (1984) mencatat 59 spesies gulma yang memiliki potensi alelopati. Inderjit dan Keating (1999) melaporkan 112 spesies gulma, bahkan Qasem dan Foy (2001) menambahkannya hingga 239 spesies. Selain itu, Qasem dan Foy (2001) mencatat 64 spesies gulma yang bersifat alelopati terhadap gulma lain, 25 spesies gulma yang bersifat autotoxic/autopathy, dan 51 spesies gulma aktif sebagai antifungi atau antibakteri. Jenis gulma yang memberikan pengaruh negatif alelopati pada tanaman berkontribusi pada berkurangnya jumlah dan kualitas panen tanaman melalui alelopati dan 
juga kompetisi sarana tumbuh. Tujuan dari penelitian ini dilaksanakan adalah untuk mengetahui respons pertumbuhan dan hasil tanaman kedelai akibat alelopati, yang terjadi akibat kehadiran gulma kaitannya dengan ukuranbenih kedelai yang berbeda.

\section{Bahan dan Metode}

Percobaan telah dilaksanakan dirumah kaca Fakultas Pertanian Universitas Padjadjaran, Jatinangor, Kabupaten Sumedang, Jawa Barat. Percobaan dilakukan mulai dari Oktober 2014 sampai Desember 2014.

Alat-alat yang digunakan adalah pot, selang, meteran, timbangan manual, timbangan analitik, cangkul, ember, tali raffia, cutter, gunting, ember, garuk, penggaris, kertas label, ajir, paku, termohygrometer, dan alat tulis. Bahan yang digunakan dalam percobaan ini adalah gulma Ageratum conyzoidesdan Borreria alata, benih kedelai varietas Grobogan (benih ukuran besar), Gema (benih ukuran sedang), dan Gepak Kuning (benih ukuran kecil) pupuk kandang, pupuk anorganik Urea, SP-36, dan $\mathrm{KCl}$, dan insektisida berbahan aktif Deltamethrin $25 \mathrm{~g} / 1$.

Penelitian ini menggunakan metode eksperimen pot bertingkat dengan Rancangan Acak Kelompok faktorial yang terdiri dari dua faktor. Faktor perlakuan pertama yaitu jenis gulma, yang terdiri dari 3 taraf yaitu jenis gulma A. Conyzoides, gulma B. alata dan tanpa gulma (kontrol). Faktor perlakuan kedua adalah jenis ukuran benih kedelai yang terdiri dari 3 taraf (varietas Gepak Kuning, varietas Gema, varietas Grobogan). Total kombinasi perlakuan adalah 9 kombinasi perlakuan, dengan 3 kali ulangan, sehingga diperoleh 27 perlakuan. Rancangan perlakuan adalah sebagai berikut :

g0k1 = Tanpa Gulma + varietas Gepak Kuning (benih ukuran kecil).

g0k2 = Tanpa Gulma + varietas Gema (benih ukuran sedang).

g0k3 = Tanpa Gulma + varietas Grobogan (benih ukuran besar).

g1k1 = Gulma A. Conyzoides + Gepak kuning (benih ukuran kecil).

g1k2 = Gulma A. Conyzoides + Gema (benih ukuran sedang).

g1k3 = Gulma A. Conyzoides + Grobogan (benih ukuran besar).

$\mathrm{g} 2 \mathrm{k} 1=$ Gulma B. Alata + Gepak kuning (benih ukuran kecil). g2k2 = Gulma B. alata + Gema (benih ukuran sedang).

g2k3 = Gulma B. alata + Grobogan (benih ukuran besar).

Analisis data percobaan akan dilakukan berdasarkan model Rancangan Acak Lengkap pola faktorial. Uji F dilakukan dengan menguji peluang dari variasi di antara nilai rata-rata perlakuan untuk mengetahui minimal sepasang perlakuan yang berbeda nyata. Jika pada taraf uji $5 \%$ nilai $\mathrm{F}_{\text {hitung }}>\mathrm{F}_{\text {tabel }}$ maka dapat dinyatakan bahwa terdapat minimal sepasang perlakuan adalah berbeda nyata. Jika dari analisis ragam nilai $F_{\text {hitung }}>$ $\mathrm{F}_{\text {tabel, }}$ dilanjutkan dengan uji lanjut Duncan pada taraf $5 \%$ untuk menguji perbe-daan antar masingmasing nilai rata-rata perlakuan.

Media tanam berupa tanah yang diperoleh dari Kebun Percobaan Fakultas Pertanian Universitas Padjadjaran dengan jenis tanah Inceptisol, kemudian ditimbang sebanyak $5 \mathrm{~kg}$ setiap potdan ditambahkan pupuk kandang $100 \mathrm{~g} /$ tanaman. Metode pot bertingkat pada penelitian ini, pot yang berisi gulma diletakan lebih tinggi dibandingkan pot yang berisi kedelai. Pada bagian bawah pot gulma dilubangi dan dimasukan selang yang kemudian dibawahnya terdapat kultivar kedelai yang berbeda.Fungsi dari selang adalah sebagai alur air yang disiram pada pot yang berisi satu pot gulma yang kemudian mengalir pada tiga pot kultivar kedelai dengan ukuran yang berbeda.

Benih kedelai sebelum ditanam, diberikan legin sebanyak 5-10 $\mathrm{ml}$ yang dicampur air sekitar $10 \mathrm{ml}$, kemudian campuran tersebut dicampur dengan $1 \mathrm{~kg}$ benih dan dicampur hingga merata (Arief, 2010). Benih kedelai ditanam dilubang tanam dengan kedalaman 2-3 cm, perlubang tanam dengan satu benih kedelai kemudian ditutup dengan tanah.Satu pot berisi tiga lubang tanaman yang diisi masing-masing satu benih kedelai. Setelah satu minggu setelah tanam dilakukan penjarangan untuk memilih tanaman yang paling baik pertumbuhannya sehingga menyisakan satu tanaman per pot. Penanaman gulma A. conyzoides, dan B. alata, masing-masing sebanyak sepuluhrumpun pada masing-masing pot. Pemupukan pada kedelai dilakukan dengan pemberian pupuk dasar urea sebanyak $50 \mathrm{~kg} / \mathrm{ha}$, pupuk SP-36 sebanyak $100 \mathrm{~kg} /$ ha dan pupuk $\mathrm{KCl}$ sebanyak $100 \mathrm{~kg} / \mathrm{ha}$ yang diberikan saat tanam (Balai Penelitian Tanah, 2005). Pada pot gulma, pemupukan tidak dilakukan.

Pemeliharaan tanaman kedelai meliputi kegiatan penyulaman, penjarangan, penyiraman, penyiangan dan pengendalian hama penyakit. 
Penjarangan dan penyulaman dilakukan satu minggu setelah tanam. Penjarangan dilakukan dengan menyisakan satu tanaman yang paling baik pertumbuhannya serta bebas dari serangan hama dan penyakit. Penyulaman dilakukan pada tanaman yang tidak tumbuh atau yang mati karena diserang hama/penyakit yaitu dengan menanam benih lagi. Penyiangan dilakukan jika pada pot kedelai terdapat gulma yang tumbuh. Pengendalian hama dan penyakit dilakukan ketika mulai terlihat gejala pada pertanaman kedelai, apabila intensitas serangan hama dan penyakit rendah dilakukan penangan-an secara mekanik tetap intensitas serangan tinggi dilakukan penanganan secara kimia dengan menggunakan insektisida Thiodan 35 EC.

Pemeliharaan pada gulma meliputi kegiat-an penyiraman dan penyiangan. Penyiraman dilakukan sebanyak $200 \mathrm{ml}$ air setiap hari pada pagi. Penyiangan dilakukan pada pot gulma terdapat gulma yang tumbuh tidak dikehendaki selain Ageratum conyzoides, dan Borreria alata. Panen kedelai dilakukan apabila sebagian besar daun sudah menguning, buah mulai berubah warna dari hijau menjadi kuning kecoklatan, atau polong sudah kelihatan tua, batang berwarna kuning agak coklat. Pengamatan penunjang dilakukan untuk menunjang pengamatan utama dan tidak dilakukan analisis secara statistik. Pengamatan utama dilakukan terhadap variabel yang dipengaruhi secara langsung oleh setiap perlakuan dan data yang diperoleh dianalisis secara statistik. Suhu udara harian, dihitung menggunakan termometer yang diletakan dalam rumah kaca. Komponen Pertumbuhan terdiri dari Tinggi tanaman $(\mathrm{cm})$ dilakukan pada 2, 46 dan 8 minggu setelah tanam (mst), jumlah daun dihitung pada 2 mst, 4 mst, 6 mst dan 8 mst. Luas Daun $\left(\mathrm{cm}^{2}\right)$ pada 42 hari setelah tanam (hst). Komponen hasil terdiri dari jumlah polong isi per tanaman, jumlah biji per tanaman (butir biji), bobot biji per tanaman (g), rata-rata bobot 100 biji (g).

\section{Hasil dan Pembahasan}

Tinggi Tanaman. Pengamatan tinggi tanaman dilakukan dengan interval 2 minggu. Tinggi tanaman mulai diamati mulai umur 2 mst pada saat tanaman kedelai sudah memasuki masa vegetatif awal dan pengamatan akhir terhadap tinggi tanaman dilakukan pada umur $8 \mathrm{mst}$ karena pada masa ini merupakan masa vegetatif berakhir dimana tanaman kedelai memasuki masa menjelang pemasakan buah.

Tabel 1. Pengaruh Perlakuan Spesies Gulma terhadap Tinggi Tanaman Kedelai dengan Ukuran dan Jenis Benih yang Berbeda.

\begin{tabular}{lrcc}
\hline \hline Perlakuan & \multicolumn{3}{c}{ Pengamatan } \\
\cline { 2 - 4 } & $2 \mathrm{mst}$ & $4 \mathrm{mst}$ & $6 \mathrm{mst}$ \\
\hline Varietas & & & \\
k1 & $14,44 \mathrm{a}$ & $72,00 \mathrm{a}$ & $97,33 \mathrm{a}$ \\
k2 & $14,77 \mathrm{a}$ & $67,89 \mathrm{a}$ & $98,11 \mathrm{a}$ \\
k3 & $15,11 \mathrm{a}$ & $74,55 \mathrm{a}$ & $98,45 \mathrm{a}$ \\
\hline Jenis Gulma & & & \\
g0 & $15,44 \mathrm{a}$ & $81,11 \mathrm{~b}$ & $112,67 \mathrm{~b}$ \\
g1 & $15,00 \mathrm{a}$ & $67,88 \mathrm{a}$ & $92,00 \mathrm{a}$ \\
g2 & $13,89 \mathrm{a}$ & $65,44 \mathrm{a}$ & $89,22 \mathrm{a}$ \\
Interaksi & tn & tn & tn \\
\hline \hline Keterangan: Anga
\end{tabular}

Keterangan: Angka- angka yang diikuti huruf yang sama pada setiap kolom yang sama tidak berbeda nyata menurut Uji DMRT (Duncan) pada taraf nyata $5 \%$.

Berdasarkan hasil analisis statistik pada Tabel 1, menunjukkan tidak terdapatnya interaksi yang nyata dari dua spesies gulma terhadap tinggi tanaman pada pengamatan 2 mst. Pengaruh perlakuan jenis varietas yang berbeda dan jenis gulma yang berbeda keduanya tidak berbeda nyata begitupun pada pengaruh interaksi menunjukan tidak ada pengaruh yang berbeda. Pada pengamatan 4, dan 6 mst untuk pengaruh jenis varietas tidak berbeda nyata akan tetapi pada perlakuan jenis gulma baik $A$. conyzoides dan $B$. alata berbeda nyata dengan kontrol.

Tabel 2. Pengaruh Interaksi Perlakuan Species Gulma dan Ukuran Benih Varietas Kedelai terhadap Tinggi Tanaman 8 mst.

\begin{tabular}{cccc}
\hline \hline Perlakuan & g0 & g1 & g2 \\
\hline k1 & $119,33 \mathrm{~b}$ & $97,33 \mathrm{a}$ & $105,33 \mathrm{a}$ \\
& $\mathrm{A}$ & $\mathrm{A}$ & $\mathrm{A}$ \\
$\mathrm{k} 2$ & $118,33 \mathrm{~b}$ & $106,33 \mathrm{a}$ & $110,67 \mathrm{a}$ \\
& $\mathrm{A}$ & $\mathrm{A}$ & $\mathrm{A}$ \\
$\mathrm{k} 3$ & $116,00 \mathrm{~b}$ & $99,33 \mathrm{a}$ & $108,00 \mathrm{a}$ \\
& $\mathrm{A}$ & $\mathrm{A}$ & $\mathrm{A}$ \\
\hline \hline
\end{tabular}

Keterangan : Interaksi antara perlakuan Spesies gulma dan ukuran benih varietas kedelai teruji secara signifikan berbeda nyata. Nilai yang diikuti oleh huruf yang sama tidak berbeda nyata menurut Uji Duncan taraf $5 \%$. Huruf besar dibaca vertikal dan huruf kecil dibaca horizontal 
Pada pengamatan $8 \mathrm{mst}$, terjadi interaksi antara jenis varietas dan jenis gulma secara signifikan berbeda nyata, hal ini menandakan perlakuan varietas Grobogan dan perlakuan kontrol memberikan pengaruh interaksi yang siginifikan terhadap tinggi tanaman yang terbaik.

Jumlah Daun Trifoliat. Berdasarkan hasil analisis statistik pada Tabel 3, pengaruh jenis spesies gulma terhadap jumlah daun kedelai dengan ukuran benih yang berbeda menunjukan tidak terdapatnya pengaruh yang nyata pada saat 2 mst. Perlakuan varietas Gepak Kuning, Gema dan juga Grobogan ketiganya tidak memberikan pengaruh yang berbeda nyata diantara sesamanya. Dilihat dari hasil analisis statistik, perlakuan dengan jumlah daun terbanyak untuk pengamatan 2 mst adalah varietas Gema, begitu juga pada pengaruh jenis gulma pengamatan 2 mst tidak memberikan pengaruh nyata. Pada umur 4 dan 6 mst, hasil analisis menunjukkan tidak terdapatnya pengaruh yang nyata diantara sesama perlakuan varietas, walaupun jumlah daun tertinggi terdapat pada varietas Grobogan (k3) khususnya pada pengamatan $6 \mathrm{mst}$, sedangkan pada pengaruh perlakuan jenis gulma berbeda nyata diantaranya, dimana perlakuan jenis gulma baik itu Ageratum dan Borreriatidak berbeda nyata tetapi berbeda nyata dengan dengan Perlakuan kontrol atau tanpa gulma. Pada umur $8 \mathrm{mst}$ perlakuan k3 (varietas grobogan) memberikan pengaruh yang berbeda nyata dengan perlakuan varietas gepak kuning (k1) dan varietas Gema $\mathrm{k} 2$, sedangkan untuk pengaruh jenis gulma perlakuan kontrol (g0) masih tetap berbeda nyata dengan kedua jenis gulma lainnya baik itu pada pengamatan $2,4,6$, dan 8 mst.

Data hasil statistik untuk jumlah daun menunjukkan bahwa tidak ada interaksi di antara kedua perlakuan varietas dan ekstrak gulma pada semua tahapan pengamatan, sehingga dua jenis gulma utama tidak mampu mempengaruhi jumlah daun kedelai. Begitu pula pada umur 6 mst, tidak memberikan pengaruh yang berbeda nyata jika dibandingkan dengan varietas dan jenis gulma yang sama. Hal itu sesuai dengan pendapat (Yu et al., 2003 dalam Yudisthira et al., 2013) umur yang lebih tua mencerminkan bahwa kemampuan beradaptasi dengan lingkungan semakin cepat, semakin cepat tanaman beradaptasi berkaitan dengan kemampuan tanaman dalam beradaptasi dengan lingkungan.
Tabel 3. Pengaruh Perlakuan Spesies Gulma dan Ukuran Benih terhadap Jumlah DaunTrifoliat.

\begin{tabular}{ccccc}
\hline \hline Perlakuan & \multicolumn{4}{c}{ Pengamatan } \\
\cline { 2 - 5 } & $2 \mathrm{mst}$ & $4 \mathrm{mst}$ & $6 \mathrm{mst}$ & $8 \mathrm{mst}$ \\
\hline Varietas & & & & \\
k1 & $1,44 \mathrm{a}$ & $4,56 \mathrm{a}$ & $7,78 \mathrm{a}$ & $13,56 \mathrm{a}$ \\
k2 & $1,56 \mathrm{a}$ & $4,56 \mathrm{a}$ & $7,67 \mathrm{a}$ & $14,55 \mathrm{a}$ \\
k3 & $1,55 \mathrm{a}$ & $4,33 \mathrm{a}$ & $8,33 \mathrm{a}$ & $16,88 \mathrm{~b}$ \\
\hline Jenis Gulma & & & & \\
g0 & $1,78 \mathrm{a}$ & $5,11 \mathrm{~b}$ & $9,22 \mathrm{~b}$ & $16,89 \mathrm{~b}$ \\
g1 & $1,51 \mathrm{a}$ & $4,12 \mathrm{a}$ & $6,88 \mathrm{a}$ & $13,78 \mathrm{a}$ \\
g2 & $1,67 \mathrm{a}$ & $4,23 \mathrm{a}$ & $7,67 \mathrm{a}$ & $14,33 \mathrm{a}$ \\
Interakasi & tn & tn & tn & th \\
\hline \hline
\end{tabular}

Keterangan: Angka- angka yang diikuti huruf yang sama pada setiap kolom yang sama tidak berbeda nyata menurut Uji DMRT (Duncan)pada taraf nyata $5 \%$.

Luas Daun. Data analisis statistik pengaruh alelopati dua spesies gulma dengan ukuran benih kedelai yang berbeda terhadap luas daun dan uji lanjut DMRT (Duncan) pada taraf $5 \%$ tercantum pada Tabel 4. Luas daun menentukan laju fotosintesis per satuan tanaman, dan luas daun dapat digunakan untuk mengukur produktifitas biomassa awal tanaman, yang berfungsi sebagai modal dalam menghasilkan bahan tanaman baru (Sitompul dan Guritno, 1995). Luas daun merupakan parameter pertumbuhan yang menentukan dalam parameter bobot kering total tanaman dan juga parameter hasil, terutama bobot segar panen per hektar (Carora $d k k, 2013$ ).

Berdasarkan Tabel 4, pengaruh dua jenis gulma terhadap ukuran benih yang berbeda dengan parameter luas daun menunjukan bahwa ukuran benih besar k3 (varietas Grobogan) mempunyai luas daun yang lebih besar dari varietas Gepak Kuning (k1) dan varietas Gema (k2) yang dicobakan, akan tetapi diantara varietas tidak ada pengaruh yang berbeda nyata secara mandiri. Pada pengaruh perlakuan jenis gulma menunjukan bahwa perlakuan jenis gulma baik $A$. conyzoides maupun $B$. alata tidak berbeda nyata, akan tetapi berbeda nyata dengan perlakuan kontrol terhadap luas daun varietas kedelai yang dicobakan. Luas daun juga mempengaruhi proses transpirasi. Makin luas permukaan daun maka makin besar transpirasinya (Kimball, 1994). Menurut hasil penelitian Damanik $d k k$ (2013) perlakuan biji besar diperoleh tinggi tanaman menjadi lebih tinggi dan jumlah cabang semakin banyak berkorelasi positif dengan jumlah luas daun yang semakin lebar. Hasil penelitian Purwanto dan Agustono (2010) menunjukkan bahwa luas daun kedelai dipengaruhi oleh 
interaksi cekaman kekeringan dan populasi awal gulma teki, luas daun tertinggi dicapai pada kapasitas tanpa gulma dan mulai menurun pada kadar air $60 \%$ kapasitas lapang dan populasi awal gulma $5 \mathrm{~g}$ per polibeg dengan rerata $330,62 \mathrm{~cm}^{2}$, luas daun akan terus menurun dengan meningkatnya taraf cekaman kekeringan dan populasi awal gulma.

Tabel 4. Pengaruh Perlakuan Jenis Spesies Gulma terhadap Luas Daun Kedelai dengan Ukuran Benih yang Berbeda (Umur 42 hst).

\begin{tabular}{lc}
\hline \hline Perlakuan & Luas daun $\left.\mathbf{( c m}^{\mathbf{2}}\right)$ \\
\hline Ukuran Benih & \\
k1 & $245,69 \mathrm{~b}$ \\
k2 & $227,49 \mathrm{a}$ \\
k3 & $266,56 \mathrm{c}$ \\
\hline Jenis Gulma & \\
g0 & $380,04 \mathrm{~b}$ \\
g1 & $194,53 \mathrm{a}$ \\
g2 & $208,77 \mathrm{a}$ \\
Interaksi $(a \geq 0,05)$ & tn \\
\hline \hline
\end{tabular}

Keterangan : Angka-angka yang diikuti huruf yang sama pada setiap kolom yang sama tidak berbeda nyata menurut Uji DMRT (Duncan) pada taraf nyata $5 \%$.

Komponen Hasil. Komponen hasil dari percobaan pot bertingkat diantaranya adalah parameter jumlah polong pertanaman, jumlah biji pertanaman, bobot biji pertanaman dan bobot 100 biji.

Berdasarkan hasil analisis statistik terhadap parameter jumlah polong pertanaman yang disajikan pada Tabel 5 dengan uji DMRT (Duncan) taraf $5 \%$ diketahui bahwa pengaruh perlakuandiantara ketiga jenis ukuran benih varietas yang dicobakan berbeda nyata diantara sesamanya, dimana varietas Gema (k2) mempunyai jumlah polong yang relatif sedikit dan berbeda nyata dengan varietas k1 (Gepak Kuning) dan juga dengan varietas Grobogan (k3). Jumlah polong varietas Gepak Kuning lebih sedikit dari ketiga jenis varietas lainnya. Varietas Grobogan tetap memberikan jumlah polong yang lebih banyak diantara ketiga jenis varietas yang dicobakan, sedangkan untuk pengaruh perlakuan gulma yang mengandung alelopati terhadap jumlah polong pertanaman dengan ukuran benih yang berbeda, baik gulma $A$. conyzoides maupun $B$. alatatidak memberikan pengaruh yang nyata bila dibandingkan dengan kontrol. Pengaruh interaksi diantara kedua perlakuan Varietas dan perlakuan jenis gulma terlihat tidak berpengaruh nyata dengan nilai signifikasi 0,246 atau $a \geq 0,05$
Tabel 5. Pengaruh Perlakuan Jenis Spesies Gulma Terhadap Komponen Hasil Kedelai dengan Ukuran dan Jenis Benih yang Berbeda.

\begin{tabular}{|c|c|c|c|}
\hline \multirow[b]{2}{*}{ Perlakuan } & \multicolumn{3}{|c|}{ Pengamatan } \\
\hline & $\begin{array}{c}\text { Jml polong } \\
\text { Pertanaman } \\
\text { (Polong) }\end{array}$ & $\begin{array}{c}\text { Jml Biji } \\
\text { Pertanaman } \\
\text { (Butir) }\end{array}$ & $\begin{array}{c}\text { Bobot Biji } \\
\text { Pertanaman } \\
\text { (g) }\end{array}$ \\
\hline \multicolumn{4}{|l|}{ Varietas } \\
\hline k1 & 24,56 a & $103,68 \mathrm{a}$ & $7,32 \mathrm{a}$ \\
\hline k2 & $25,11 \mathrm{ab}$ & 105,33 a & $8,38 \mathrm{~b}$ \\
\hline k3 & $26,55 \mathrm{~b}$ & $109,65 \mathrm{~b}$ & $14,65 \mathrm{c}$ \\
\hline \multicolumn{4}{|l|}{ Jenis Gulma } \\
\hline g0 & $28,44 \mathrm{~b}$ & $112,32 \mathrm{~b}$ & $15,75 \mathrm{~b}$ \\
\hline g1 & 24,45 a & 101,35 a & $7,59 \mathrm{a}$ \\
\hline g2 & 24,34 a & 101,02 a & 7,13 a \\
\hline Interaksi & tn & tn & th \\
\hline
\end{tabular}

Hasil analisis statistik terhadap jumlah biji pertanaman yang disajikan pada Tabel 5 menunjukkan bahwa, pengaruh perlakuan varietas berbeda nyata diantara sesamanya. Jumlah biji pertanaman pada varietas Gepak Kuning lebih banyak dari varietas Gema namun diantara keduanya tidak berbeda secara nyata. Akan tetapi kedua varietas tersebut berbeda nyata dengan varietas Grobogan, untuk pengaruh perlakuan jenis gulma terlihat bahwa kedua jenis gulma baik $A$. conyzoides maupun $B$. alata tidak berbeda nyata, akan tetapi berbeda nyata dengan perlakuan kontrol $(\mathrm{g} 0)$, sementara pengaruh interaksi diantara kedua perlakuan dengan nilai signifikasi 0,242 atau lebih besar dari $(a \geq 0,05)$, yang berarti kedua perlakuan tidak berbeda nyata. Bobot Biji Pertanaman yang terlihat pada Tabel 5 dengan uji DMRT (Duncan) pada taraf $5 \%$ diketahui bahwa pengaruh dua spesies gulma terhadap Bobot Biji Pertanaman kedelai dengan ukuran benih yang berbeda, tidak memberikan pengaruh yang nyata diantara kedua jenis gulma yang dicobakan. Berdasarkan hasil analisis statistik pada Tabel 5 diketahui bahwa pengaruh alelopati duaspesies gulma terhadap bobot biji pertanaman kedelai dengan ukuran benih yang berbeda, tidak memberikan pengaruh yang nyata.

Pada bobot 100 biji yang tertera pada Tabel 6 terlihat pengaruh interaksi perlakuan ukuran jenis varietas tanaman kedelai sangat berbeda nyata diantara sesama vaietas, begitupun pengaruh jenis gulma berbeda nyata. Perlakuan g0 secara signifikan berbeda nyata terhadap g1 dan g2 pada ukuran benih kecil, begitupun 
perlakuan g0 pada ukuran benih terlihat bahwa k1 (Benih Kecil) berbeda nyata dengan k2 (Benih Sedang) dan k3 (Benih Besar).

Tabel 6. Pengaruh Interaksi Perlakuan Jenis Spesies Gulma dan Ukuran Benih Kedelai terhadap Komponen Hasil Bobot 100 Biji.

\begin{tabular}{cccc}
\hline \hline Perlakuan & g0 & g1 & g2 \\
\hline k1 & $7,71 \mathrm{~b}$ & $5,40 \mathrm{a}$ & $5,56 \mathrm{a}$ \\
& $\mathrm{A}$ & $\mathrm{A}$ & $\mathrm{A}$ \\
$\mathrm{k} 2$ & $9,20 \mathrm{~b}$ & $7,65 \mathrm{a}$ & $7,67 \mathrm{a}$ \\
& $\mathrm{B}$ & $\mathrm{B}$ & $\mathrm{B}$ \\
$\mathrm{k} 3$ & $14,39 \mathrm{~b}$ & $11,27 \mathrm{a}$ & $12,45 \mathrm{a}$ \\
& $\mathrm{C}$ & $\mathrm{C}$ & $\mathrm{C}$ \\
\hline
\end{tabular}

Keterangan : Interaksi antara perlakuan Spesies gulma dan ukuran benih varietas kedelai teruji secara signifikan berbeda nyata. Nilai yang diikuti oleh huruf yang sama tidak berbeda nyata menurut Uji Duncan taraf $5 \%$. Huruf besar dibaca vertikal dan huruf kecil dibaca horizontal

Kedua faktor perlakuan baik ukuran benih varietas kedelai maupun jenis gulma berbeda nyata diantara sesamanya. Varietas Grobogan tetap memberikan bobot 100 biji yang paling besar dibandingkan dengan varietas Gepak Kuning (k1) maupun varietas Gema (k2), hal ini tentu juga sesuai dengan deskripsi dari tiap-tiap varietas yang dicobakan. Untuk pengaruh perlakuan jenis gulma terlihat bahwa gulma baik gulma $A$. conyzoides maupun $B$. alata tidak berbeda nyata akan tetapi berbeda secara nyata bila dibandingkan dengan perlakuan kontrol g0 (tanpa gulma).

Hasil analisis statistik pada Tabel 5 dan 6 percobaan pot bertingkat ini memberikan informasi bahwa hampir sebagian besar para-meter yang diamati pada komponen pertum-buhan memperlihatkan pengaruh perlakuan ukuran benih varietas yang dicobakan tidak berbeda nyata, kecuali pada pengamatan jumlah daun 8 mst komponen pertumbuhan, dimana varietas Grobogan mempunyai jumlah daun yang lebih banyak dibandingkan kedua jenis varietas lainnya, begitupun pada pengaruh interaksi hanya terdapat pada parameter tinggi tanaman pengamatan 8 mst. Pendapat Xue, (2007 dalam Yudisthira et al., 2013) umur yang lebih tua mencerminkan bahwa kemampuan beradaptasi tanaman dengan lingkungan semakin baik, semakin cepat tanaman beradap-tasi maka semakin baik pula pertumbuhan dan hasilnya.

Pada parameter komponen hasil terlihat bahwa jumlah polong, jumlah biji pertanaman, bobot biji pertanaman pengaruh perlakuan jenis varietas berbeda nyata diantara sesamanya, sementara untuk pengaruh jenis gulma diantara gulma $A$. conyzoides dan $B$. alata tidak berbeda nyata kecuali pada parameter bobot 100 biji, walaupun tidak berbeda nyata secara statistik uji lanjut Duncan $5 \%$, namun pengaruh dari jenis gulma $A$. conyzoides terhadap parameter yang diuji dari data yang ada menunjukan bahwa nilai dari tiap-tiap parameter komponen hasil jumlahnya lebih sedikit hasilnya bila dibandingkan dengan pengaruh jenis gulma $B$. alata. Hal ini disebabkan karena Gulma A. conyzoides Linn, merupakan salah satu dari sekian banyak gulma yang dapat menekan pertumbuhan tanaman budidaya. A. conyzoides seringkali populasinya lebih dominan dibandingkan gulma lainnya dalam suatu lahan. A. conyzoides mempunyai alelopati, keadaan di mana suatu gulma atau bahan tanaman mengeluarkan eksudat kimia yang dapat menekan pertum-buhan tanaman/ tumbuhan lainnya (Sukman dan Yakup, 1991). Hasil penelitian Xuan et al (2004) bahwa penggunaan daun $A$. conyzoides dengan dosis 2 ton/ha dapat menekan sampai $75 \%$ pertumbuhan beberapa gulma pada tanaman padi. Selanjutnya kemampuan daun $A$. conyzoides sebagai alelopati diidentifikasikan karena adanya asamfenolik yang dapat menghambat pertumbuhsn beberapa tanaman budidaya.

Penghambatan terhadap tanaman karena alelopati yang terkandung di dalam cairan perasan daun A. conyzoides, yaitu senyawa fenol dapat menghambat enzim pertumbuhan Indol asetat (IAA) dan giberelin (GA) (Sastroutomo, 1990). Aktivitas GA diketahui berperan di dalam merangsang pertumbuhan, sehingga apabila enzim tersebut terhambat maka pertumbuhan juga terhambat, dan dalam hal ini tanaman kedelaiakan terhambat. Penghambatan lebih besar pada tanaman lebih muda karena aktivitas enzim pertumbuhan umumnya sangat aktif pada tanaman muda dibandingkan tanaman yang lebih dewasa. Hasil penelitian Aini (2008) juga menunjukkan penghambatan akibat pem-berian ekstrak $A$. conyzoides yang mempunyai senyawa alelopati dapat menghambat pertumbuhan tanaman. Selanjutnya hasil penelitian Javaaurora (2010) dalam Hafsah, dkk (2012) menjelaskan bahwa pemberian $A$. conyzoides dapat menghambat pertumbuhan kacang hijau.Pada Tabel 5 diketahui bahwa pengaruh alelopati dua spesies gulma $A$. conyzoidesdan $B$. Alata terhadap sejumlah parameter komponen hasil yang diamati pada kedelai 
dengan ukuran benih yang berbeda, memberikan perbedaan yang nyata pada setiap taraf perlakuan varietas, begitu juga perlakuan kontrol pada taraf jenis gulma memberikan pengaruh yang berbeda nyata terhadap efek alelopati. Hal ini membuktikan bahwa semakin kecil ukuran benih maka akan semakin mudah terganggu. Kaitannya dengan peristiwa ini, jenis kedelai Gepak Kuning (k1) terganggu oleh adanya pengaruh alelopati yang dihasilkan oleh gulma. Menurut Sutopo (2004), bobot atau ukuran benih mempengaruhi pertumbuhan dan produksi benih, karena semakin besar ukuran benih maka semakin besar pula energinya dan diduga lebih cepat beradaptasi terhadap lingkungan dan keberadaan gulma. Diduga benih dengan ukuran besar lebih tahan terhadap efek alelopati jika dibandingkan dengan benih yang berukuran kecil.

\section{Kesimpulan dan Saran}

1. Percobaan pot bertingkat ini memberikan informasi bahwa hampir sebagian besar parameter yang diamati pada komponen pertumbuhan memperlihatkan pengaruh perlakuan ukuran benih varietas yang dicobakan tidak berbeda nyata, kecuali pada pengamatan jumlah daun 8 mst komponen pertumbuhan, dimana varietas Grobogan mempunyai jumlah daun yang lebih banyak dibandingkan kedua jenis varietas lainnya, begitupun pada pengaruh interaksi hanya terdapat pada parameter tinggi tanaman pengamatan 8 mst.

2. Jumlah polong, jumlah biji pertanaman, bobot biji pertanaman dipengaruhi oleh perlakuan jenis varietas, pengaruh jenis gulma diantara gulma $A$. conyzoides dan $B$. alata tidak menunjukkan perbedaan, kecuali pada parameter bobot 100 biji, walaupun tidak berbeda,tetapi pengaruh dari jenis gulma $A$. conyzoides terhadap komponen hasil jumlahnya lebih sedikit hasilnya bila dibandingkan dengan pengaruh jenis gulma B. alata

3. Disarankan untuk melakukan penelitain lanjutan dengan mencoba jenis gulma lain selain Ageratum conyzoides dan Borerria alatayang mengandung alelopati terhadap jenis varietas kedelai yang berbeda.

\section{Ucapan Terima Kasih}

Penulis mengucapkan terima kasih kepada Kepala Kebun dan Rumah Kaca Fakultas Pertanian Universitas Padjadjaran yang telah mengizinkan untu pemakaian alat dan rumah kaca tempat penelitian berlangsung serta pegawai dan staf di Rumah Kaca Fakultas Pertanian Unpad.

\section{Daftar Pustaka}

Aini, B. 2008. Pengaruh ekstrak alang-alang (Imperata cylindrica), bandotan (Ageratum conyzoides) dan teki (Cyperus rotundus) terhadap perkecambahan beberapa varietas kedelai (Glycine max L).

Arief. 2010. Pembibitan Kedelai. http://epetani. deptan.go.id/budidaya/pembibitan-kedelai-55. Diakses 8 Maret 2014.

Balai Penelitian Tanah. 2005. Rekomendasi Pemupukan Tanaman Kedelai pada Berbagai Tipe Penggunaan Lahan. Balai Penelitian Tanah : Bogor.

Carora, Wicaksono, dan H.B. Heddy. 2013. Pengaruh pemberian bioaktivator terhadap pertumbuhan dan hasil tanaman bawang merah (Allium ascolonicum L.). Diakses pada Proton studenjournal.ub.ac.id. Diakses 28 Agustus 2008.

Chozin, M.A. 2006. Peran Ekofisiologis Tanaman Dalam Pengembangan Teknologi Budidaya Pertanian. Orasi Ilmiah Guru Besar Tetap Ilmu Agronomi. Faperta IPB. $114 \mathrm{hlm}$.

Damanik, A.F., Rosmayati, dan H. Hasmawi. 2013. Respons pertumbuhan dan produksi kedelai terhadap pemberian mikoriza dan penggunaan ukuran biji pada tanah salin. J. Online Agroekoteknologi Vol.1, No.2,

Guang, X. 1997. Study on Application Techniques of Oxyfluorfen in Garlic. Proceeding, Sixteenth Asian-Pasific Weed Science Society Confrerence. Published by Malaysian Plant Protection Society.

Hafsah S., M.A. Ulim, dan C. M. Nofayanti, 2012. Efek alelopati Ageratum conyzoides terhadap pertumbuhan sawi. Jurnal Floratek. 8(4)18-24.

Inderjit dan K.I Keating. 1999. Allelopathy: principles, procedures, processes, and promises for biological control. dalam: Sparks DL (ed). Adv Agron Vol 67. San Diego: Acad Pr. hlm 141-231. 
Javaaurora. 2010. Daun wedusan (Ageratum conyzoides L.) ternyata mampu menghambat pertumbuhan tinggi tanaman dan jumlah daun kacang hijau (Phaseollus radiatus). http://erickbio.wordpress.com /2010/07/01/ (diakses 23 Maret 2014).

Kimball.1994. Biologi Jilid 2. Erlangga: Jakarta.

Madkar, O.R., T. Kuntohartono, S. Mangoensoekardjo. 1986. Masalah Gulma dan Pengendalian. HIGI. Bogor.

Purwanto dan T. Agustono. 2010. Kajian fisiologi tanaman kedelai pada kondisi cekaman kekeringan dan berbagai kepadatan gulma teki. Jurnal Agrosains 12(1): 24-28.

Qasem, J. and C.L.R. Foy. 2001. Weed allelopathy, its ecological impacts and future prospects: a review. Jounal Crop. Prod. 4:43-119.

Rice, E.L. 1984. Allelopathy. Second Edition Acad. Press N.Y.

Roesmiyanto, F., Kasyadi, Suyamto, E. Retnaningsih dan S. Yuniastuti, 1999. Teknologi budidaya kedelai dalam Makalah Seminar Gema Palagung Jawa Timur. BPTP Karangploso, Malang.

Sastroutomo, 1990. Ekologi Gulma. Jakarta. PT Gramedia Pustaka Utama. Hal. 142.
Smith, R.G.D. 1985. Ecology and Field Biology. 2nd Ed. Harper and Row. New York. Evanson San Fransisco. London Pp 169

Sukman, Y. dan Yakub. 1999. Gulma dan Teknik Pengendaliannya. Fakultas Pertanian Unsri Palembang. $157 \mathrm{hlm}$.

Susilo, E. 2004. Penerapan Sistem Budidaya dan Cara Pengendalian gulma pada Kacang Kedelai (Glycine max (L) Merr) dan Padi (Oriza sativa L) dalam Pola Tumpangsari. Thesis Sekolah Pasca Sarjana IPB.

Sutopo, L. 2004. Teknologi Benih (edisi revisi). Raja Grapindo Persada. Jakarta.

Utomo, I.H., P. Lontoh, Rosilawati dan Handayaningsih. 1986. Kompetisi Teki dan Gelang dengan Tanaman Hortikultura. Prosiding Konferensi VIII HIGI. Bandung.

Xuan, T.D., N.H. Honh, T. Ediji, and T.D. Khanh. 2004. Paddy weed control by higher plants from Southeast Asia. Crop. Prot. Journal. 23:255-26.

Yudisthira, Roviq dan Wardiyanti. 2013. Pertumbuhan dan produktivitas sawi pak choy (Brasica rapa L.) pada umur transplanting dan pemberian mulsa organik. http://protan.studentjournal.ub.ac.id. Diakses tanggal 8 Agustus 2014. 